\title{
Putting Plant Genetic Diversity and Variability at Work for Breeding: Hybrid Rice Suitability in West Africa
}

\author{
Raafat El-Namaky ${ }^{1}$, Mamadou M. Bare Coulibaly ${ }^{2}$, Maji Alhassan 1,3, Karim Traore 1, \\ Francis Nwilene ${ }^{4}$, Ibnou Dieng ${ }^{5}$, Rodomiro Ortiz ${ }^{6, *}$ and Baboucarr Manneh ${ }^{1}$ \\ 1 Africa Rice Center (Africa Rice) Sahel Station, B.P. 96 Saint Louis, Senegal; R.Elnamaky@cgiar.org (R.E.-N.); \\ A.Maji@cgiar.org (M.A.); K.Traore@cgiar.org (K.T.); B.Manneh@cgiar.org (B.M.) \\ 2 Institute of Rural Economy (IER), B.P. 258 Bamako, Mali; mamadoumbare@yahoo.fr \\ 3 National Cereals Research Institute (NCRI), Badeggi, P.M.B. 8 Bida, Niger State, Nigeria \\ Africa Rice Center, Ibadan, P.M.B. 5320 Oyo State, Nigeria; F.Nwilene@cgiar.org \\ Africa Rice, 01 B.P. 2031 Cotonou, Benin; I.Dieng@cgiar.org \\ 6 Swedish University of Agricultural Sciences (SLU), Box 101, SE 23053 Alnarp, Sweden \\ * Correspondence: rodomiro.ortiz@slu.se; Tel.: +46-725418386
}

Received: 17 April 2017; Accepted: 7 July 2017; Published: 10 July 2017

\begin{abstract}
Rice is a staple food in West Africa, where its demand keeps increasing due to population growth. Hence, there is an urgent need to identify high yielding rice cultivars that fulfill this demand locally. Rice hybrids are already known to significantly increase productivity. This study evaluated the potential of Asian hybrids with good adaptability to irrigated and rainfed lowland rice areas in Mali, Nigeria, and Senegal. There were 169 hybrids from China included in trials at target sites during 2009 and 2010. The genotype $\times$ environment interaction was highly significant $(p<0.0001)$ for grain yield indicating that the hybrids' and their respective cultivar checks' performance differed across locations. Two hybrids had the highest grain yield during 2010 in Mali, while in Nigeria, four hybrids in 2009 and one hybrid in 2010 had higher grain yield and matured earlier than the best local cultivar. The milling recovery, grain shape and cooking features of most hybrids had the quality preferred by West African consumers. Most of the hybrids were, however, susceptible to African rice gall midge (AfRGM) and Rice Yellow Mottle Virus (RMYV) isolate Ng40. About $60 \%$ of these hybrids were resistant to blast. Hybrids need to incorporate host plant resistant for AfRGM and RYMV to be grown in West Africa.
\end{abstract}

Keywords: Oryza sativa; adaptability; food security; genotype $\times$ environment interaction; grain yield; heterosis; hybrid vigor; quality; resilience; sustainability

\section{Introduction}

Rice (Oryza sativa L.) is the most important staple food crop in the world. About 3.5 billion people depend on rice globally, since this staple provides in excess of $20 \%$ of their daily calorie intake [1]. In Africa alone, where currently rice consumption is the most rapidly growing food source, about 30 million $t$ more rice will be required by 2035, thus representing an increase of $130 \%$ in rice consumption from 2010. Nigeria would require almost one third of this additional rice [2]. More than $90 \%$ of West African rice farmers are smallholders (mostly women) who cultivate less than 1 ha and whose crop yields depend on rainfall. Crop production from these small plots is often insufficient to provide a reasonable household income for maintaining a minimum standard of living. These farmers manage complex farming systems, cultivating rice and other food crops based on its degree of importance as food and as a cash crop, unlike farmers in Asia, where rice is a crop mainly grown in lowland and irrigated agro-ecosystems. The major constrains of global rice production are drought, flood, heat, pathogens, pests, declining productivity in intensive rice production systems, low 
grain yield in some areas of the developing world, increasing production costs in the industrialized world, and rising public concern regarding sustainability of rice farming. In addition, mechanization, the high cost of irrigated rice production, as well as the poor management of uplands and rainfed lowlands are among the main challenges for producing rice in Africa [3,4].

Advances in rice production in Africa are at various developmental stages due to its relative importance to respective local economy. Hybrid rice seed technology is key for increasing its production and maintaining self-sufficiency and food security. Hybrid rice has been used in rice production for more than 40 years in Asia and North America, and more recently in Egypt because of its high grain yield potential. This yield advantage plus water and nitrogen use efficiency, and host plant resistance to pathogens and pests are the main determining factors for adapting hybrid seed technology in rice production. Heterosis improves grain yield and quality for many crops especially when facing a limited area for farming. Hybrid cultivars have been developed to take advantage of heterosis in the production of many field crops such as cotton, maize, oilseed rape, rice, sorghum, sunflower, and vegetables $[5,6]$. African farmers may boost rice production by using hybrids particularly in the largely unutilized lowland rice areas. Mali, Nigeria, and Senegal are willing to adopt this seed technology to increase their rice production.

Rice breeders in China led the developing and commercializing of rice hybrids that had 15 to $20 \%$ yield advantage [7] or at least $1 \mathrm{tha}^{-1}$ [8] over inbred cultivars. The new set of Green Super Rice (GSR) hybrids need less chemical inputs to increase grain yields than the old rice hybrids. Likewise, many of these GSR hybrids show adaptation to drought, thereby requiring less water and could be grown in rainfed agro-ecosystems. Nonetheless, their adaptability to African farming systems needs to be assessed across target areas, as well as the relative inputs they require vis-à-vis local cultivars. Farmers need to invest in both seeds and inputs for getting high grain yields when using rice hybrids. The increased grain yield of rice hybrids should pay for this investment and bring profitability to those using this seed technology.

There are various pathogens and pests affecting rice production in Africa. The African rice gall midge (AfRGM; Orseolia oryzivora; Diptera: Cecidomyiidae) is an important insect pest in irrigated lowland rice areas, causing 25 to $80 \%$ grain yield loss in West Africa [9]. AfRGM is an endemic pest to Africa, where was first reported in Sudan, and currently spreading throughout the continent. It can be found in 12 West African, two Central African, and five East and Southern African countries [10]. The insect pest causes 20 to $100 \%$ grain yield loss in the worst-affected areas. There are 16 quantitative trait loci (QTL) associated with host plant resistance to AfRGM, of which three are in [ITA306 $\times$ BW348-1], five in [ITA306 $\times$ TOS14519], and eight in [ITA306 $\times$ TOG7106] breeding populations. The major effect genomic region for AfRGM resistance was in the [ITA306 $\times$ TOS14519] population, which was at $111 \mathrm{cM}$ on chromosome 4 (qAfrGM4), had a LOD score of 60 and accounted for $34.1 \%$ of the total phenotypic variance [11]. Likewise, Rice Yellow Mottle Virus (RYMV, a Sobemo virus) is another major constraint to rice production in the continent [12] because it causes 17 to $100 \%$ grain yield loss according to both the infection date and time, and the cultivar host $[13,14])$. RYMV is highly infectious to rice, especially to Asian indica cultivars in lowland and irrigated agro-ecosystem. RYMV is prevalent in all major rice growing ecosystems of Africa [15]. Rice blast, caused by Magnaporthe oryzae (anamorph: Pyricularia oryzae) [16], is another serious disease affecting rice in temperate and tropical regions, including Africa $[17,18]$.

The main purpose of this research was to determine the suitability of GSR hybrid cultivars bred in China at the irrigated lowland rice areas of Mali, Nigeria, and Senegal. We assessed their grain yield across suitable West African rice growing areas. 


\section{Materials and Methods}

\subsection{Plant Materials}

The Chinese Academy of Agricultural Sciences provided two sets of GSR hybrids consisting of 122 and $47 \mathrm{~F}_{1}$ s. Africa Rice included eight inbred rice cultivars that were used as checks because farmers in Mali, Nigeria, and Senegal grow them widely.

\subsection{Methods}

The multi-location trials were conducted during 2009 and 2010. For each country, two trials were conducted in an augmented design layout [19] in a randomized complete block (RCB), with each cultivar plot comprising of five rows of $3 \mathrm{~m}$ length with a plant to row spacing of $20 \times 20 \mathrm{~cm}$. In Senegal, 122 hybrids and 13 checks were evaluated during the 2009 wet season (June-November) at Ndiaye (the Africa Rice Research Station near Saint-Louis), and 47 hybrids were evaluated with checks during the 2010 dry season (February-June) 2010 at the Research Station of L' Institut Sénégalais de Recherche Agricole (ISRA) in Fanaye. There are two seasons in Senegal, the rainy season from June to October, characterized by heat, humidity and storms, and the dry season from December to May, characterized by cool ocean breeze and dust from the Harmattan winds. A total of 122 hybrids and 8 checks were evaluated in Mali during the 2010 dry season (January-May) at N'Debougou in the Office du Niger, and 47 hybrids and checks were evaluated during 2010 wet season (June-November) at the Agriculture Research Station in Niono. The Office du Niger irrigation scheme is the largest in West Africa and located in the Segou region of Central Mali. Rainfall in the Office du Niger area ranges from 450 to $600 \mathrm{~mm}$ per year. The rainy season lasts three to five months, and the dry season is divided into a cool and a hot period. In Nigeria, 122 hybrids and checks were evaluated during the 2009 dry season (October-April) at the research field of the National Cereals Research Institute (NCRI) in Badeggi, and 47 hybrids evaluated with eight checks during the 2010 wet season (May-October) at Wushishi. Both Nigerian locations are in the Southern Guinea Savanna, a typical rainfed lowland agro-ecology with iron toxicity and high AfRGM severity. The trials used known cultural practices of each country. The fertilizer applications varied as follows: $115-36 \mathrm{~kg} \mathrm{~N}-\mathrm{K} \mathrm{ha}^{-1}$ in Mali, $80-40-40 \mathrm{~kg} \mathrm{~N}-\mathrm{P}-\mathrm{K}$ ha $^{-1}$ in Nigeria, and 150-17.5-33 kg N-P-K ha ${ }^{-1}$ in Senegal. The data recorded in the field included plant height, panicles $\mathrm{m}^{-2}$, spikelets plant ${ }^{-1}$, 1000-grain weight and grain yield. Grain quality traits and milling properties of 18 promising hybrids were evaluated at Africa Rice Sahel Station, near Saint Louis, Senegal. The most popular cultivar Sahel 108, widely preferred by farmers and consumers, was used as grain quality check. The traits assessed were brown rice length, grain length and shape, percentage of total milling, alkali-spreading value (ASV), and gelatinization temperature (GT). A high and low GT indicates more or less energy necessary for cooking rice, respectively. All traits were measured according to the standard's evaluation system used by the International Rice Research Institute (IRRI, Manila, Philippines) [20].

\subsection{Host Plant Resistance (HPR) to AfRGM, RYMV and Blast}

The first set of 122 hybrids along with eight inbred lowland cultivars were evaluated for HPR to AfRGM at a paddy screenhouse in Ibadan, Nigeria during 2009. Two rice cultivars were used as checks: ITA 306 as susceptible and TOS14519 as resistant to AfRGM. Conventional "spreader rows" of the highly susceptible cultivar ITA 306 were around the GSR plants. Newly hatched larvae were deposited on "spreader" plants to increase infestation in the screenhouse [18]. Data were taken 45 and 70 days after transplanting (DAT) to estimate the percentage of tillers infested or damage by AfRGM. In the 2010 wet season, 47 hybrid lines and eight check cultivars were screened for resistance to AfRGM under natural infestation at Edozhigi in Niger State, Nigeria. The GSR hybrids and checks were laid out in an RCB with three replications. Data were taken at 42 and 63 DAT. Rice blast was evaluated in a trapping nursery as described by Sere, et al. [21] on blast hot spot at Ouedeme, Benin in 2009. Trapping nurseries consists of exposing cultivars with known 
resistance genes to natural inoculum. The reaction of each of the cultivars is an indication of the presence/activation (non-compatible reaction) or absence/inactivation (compatible reaction) of the corresponding avirulence genes without prejudging their association into distinct races. This trapping nursery was laid out in an RCB design. We scored disease severity weekly using IRRI's standard evaluation system [20]. Standard cultivars and near isogenic lines (NIL) were used as checks to define host plant resistance clusters to blast. A highly resistant rating was given to those hybrids similar to the cultivar check and a NIL possessing the gene Pi9, while for the resistant cluster the check was the NIL bearing the Pi2 gene. The susceptible cluster included as checks five NIL with Pi33, Pif, Pii, Pish, and Pi1b genes. Hybrids were rated as highly susceptible when showing scores similar to a susceptible check and 22 NIL. There were 122 hybrids tested against RYMV through artificial inoculation of two strains (NG-01 and NG-40) in a screenhouse. We included two resistant (Gigante and TOG 5681) and one susceptible check in this screening. RYMV was evaluated 21 and 42 days after inoculation using the standard evaluation system with a 1-9 scale, in which 1 means lack of any symptom and 9 a completely damaged leave. The disease severity score (S) was calculated as $\mathrm{S}=\left\{\left(\mathrm{n}_{1} \times 1+\mathrm{n}_{3} \times 3+\mathrm{n}_{5} \times 5+\mathrm{n}_{7} \times 7+\mathrm{n}_{9} \times 9\right) \times 100\right\} /\left\{\left(\mathrm{n}_{1}+\mathrm{n}_{3}+\mathrm{n}_{5}+\mathrm{n}_{7}+\mathrm{n}_{9}\right) \times 9\right\}$, where $\mathrm{n}_{1}, \mathrm{n}_{3}$, $\mathrm{n}_{5}, \mathrm{n}_{7}$, and $\mathrm{n}_{9}$ represent the number of plant scoring $1,3,5,7$, and 9 , respectively [22]. The following hybrid clusters were defined for both strains according to their host plant resistance scores: (1) rated as the resistant checks, (2) moderately susceptible, and (3) rated as the susceptible checks.

\subsection{Statistical Analysis}

Data were subjected to an analysis of variance using SAS/STAT 9.2 (SAS Institute, Cary, NC, USA). We investigated the genotype $\times$ country interaction $(G \times E)$ using a SAS mixed model [23]. If a significant $G \times E$ was detected, we analyzed the performance of hybrids and their respective cultivar checks within each country because they performed differently across environments. A multiple comparison adjustment for the probability $(p)$ values was then performed to test whether the adjusted means of the hybrids were significantly higher than the best check for each country at a significance level of $p \leq 0.05$.

\section{Results}

The $G \times E$ was highly significant $(p<0.0001)$ for grain yield in both sets of experiments, thereby indicating that hybrids and check cultivars performed differently across Mali, Nigeria, and Senegal. Hence, we analyzed separately each set of experiments within each country (Table 1).

Table 1. Combined analysis of variance for grain yield of two sets of hybrids and their cultivar checks across sites in Mali, Nigeria, and Senegal.

\begin{tabular}{ccccc}
\hline Source of Variation & DF $^{\mathbf{z}}$ & MSE $^{\mathbf{y}}$ & F Value & $p$ Value \\
\hline \multicolumn{5}{c}{ First set: 122 hybrids +13 inbred } \\
\hline Genotypes (G) & 134 & $4,833,250$ & 2.58 & $<0.001$ \\
Country (E) & 2 & $723,984,958$ & 386.79 & $<0.001$ \\
G $\times$ E & 240 & $4,316,391$ & 2.306 & $<0.001$ \\
Error & 117 & $1,871,732$ & \\
\hline \multicolumn{5}{c}{} \\
Genotypes (G) & Second set: 47 hybrids + 13 inbred \\
Country (E) & 59 & $6,770,649.3$ & 1.34 & 0.0990 \\
G $\times$ E & 2 & $120,454,097.3$ & 23.91 & $<0.001$ \\
Error & 111 & $6,880,333.9$ & 1.37 & 0.0496 \\
\hline
\end{tabular}

${ }^{\mathrm{z}}$ Degrees of freedom, ${ }^{\mathrm{y}}$ Mean square error. 


\subsection{Country Performance}

Most of the hybrids showed on average 10 days earlier $50 \%$ flowering than check cultivars during the 2009 wet season at Saint Louis, Senegal (Table 2a). The best yielding check cultivar, Sahel 108, had the highest number of tillers (23), while hybrids, whose grain yield was above Sahel 108, had 13 to 15 tillers. The promising hybrids QYI, HanF1-39, and HS706 exhibited panicles whose lengths were 25, 24 , and $29 \mathrm{~cm}$, respectively, while the panicle of Sahel 108 measured on average $20 \mathrm{~cm}$. There were not significant differences for average of plant height between hybrids and checks cultivars.

The average grain yield of hybrids $\left(7 \mathrm{tha}^{-1}\right)$ and checks $\left(6.5 \mathrm{tha}^{-1}\right)$ was not significantly different. Only hybrids QYI, HanF1-39, and HS706 had a significant grain yield advantage (38 to 43.5\%) vis-à-vis Sahel 108. Most of the hybrids and checks had early flowering (89 and 92 days, respectively) during the 2010 wet season at Fanaye, Senegal (Table 2b). The hybrid CNY498 was the earliest flowering (82 days) and shortest $(80 \mathrm{~cm}$ ). There was no significant difference for average plant height between hybrids $(101 \mathrm{~cm})$ and checks $(102 \mathrm{~cm})$. The check cultivars showed a higher average number of tillers plant $^{-1}$ and panicle length than the hybrids. The hybrid HS706 had the longest panicle $(29 \mathrm{~cm})$, and the hybrid XYR24 was the only one out-yielding significantly the check cultivar Sahel 108.

Table 2. Grain yield and other agronomic traits of promising rice hybrids and best cultivar check (C) at (a) Ndiaye (2009 wet season) and (b) Fanaye (2010 wet season), Senegal. The $p$-value indicates that hybrids' yield was significantly higher than Sahel 108. Standard errors (S.E.) given for each trait.

\begin{tabular}{|c|c|c|c|c|c|c|c|}
\hline Cultivar & $\begin{array}{l}\text { Days to } 50 \% \\
\text { Flowering }\end{array}$ & $\begin{array}{c}\text { Plant } \\
\text { Height }(\mathrm{cm})\end{array}$ & $\begin{array}{c}\text { Tiller } \\
\text { Plant }^{-1}\end{array}$ & $\begin{array}{c}\text { Panicle } \\
\text { Length }(\mathrm{cm})\end{array}$ & $\begin{array}{l}\text { Grain Yield } \\
\left(t \mathrm{ha}^{-1}\right)\end{array}$ & $\begin{array}{c}\text { Yield } \\
\text { Advantage (\%) }\end{array}$ & $p$-Value \\
\hline \multicolumn{8}{|c|}{ diaye 2009 Wet Season } \\
\hline Qy1 & 80 & 108 & 14 & 25 & 10.5 & 43.54 & 0.0285 \\
\hline HanF1-39 & 87 & 97 & 13 & 24 & 10.5 & 42.86 & 0.0307 \\
\hline HS706 & 87 & 108 & 15 & 29 & 10.1 & 37.96 & 0.0480 \\
\hline Sahel $108(C)$ & 88 & 86 & 23 & 20 & 7.4 & & \\
\hline Hybrid mean & 84 & 102 & 15 & 24 & 7.1 & 8.91 & \\
\hline Check mean & 94 & 101 & 18 & 27 & 6.5 & & \\
\hline Hybrid S.E. & 4 & 5 & 3 & 2 & 1.5 & & \\
\hline Check S.E. & 2 & 2 & 1 & 1 & 0.6 & & \\
\hline \multicolumn{8}{|c|}{ (b) Fanaye 2010 Wet Season } \\
\hline XYR24 & 91 & 106 & 20 & 25 & 12.2 & 82.46 & 0.027 \\
\hline CXY727 & 93 & 121 & 20 & 25 & 10.7 & 59.97 & 0.077 \\
\hline NEY2123 & 92 & 79 & 20 & 23 & 10.6 & 59.37 & 0.078 \\
\hline CNY498 & 82 & 99 & 20 & 27 & 10.5 & 57.42 & 0.085 \\
\hline 3LYR24 & 89 & 108 & 20 & 23 & 10.3 & 54.87 & 0.095 \\
\hline Sahel 108 (C) & 87 & 82 & 25 & 23 & 6.7 & & \\
\hline Hybrids mean & 89 & 101 & 21 & 21 & 6.1 & 59.74 & \\
\hline Check mean & 92 & 102 & 20 & 20 & 3.8 & & \\
\hline Hybrid S.E. & 4 & 7 & 2 & 3 & 2.0 & & \\
\hline Check S.E. & 3 & 14 & 2 & 2 & 0.9 & & \\
\hline
\end{tabular}

There were no significant differences for days to $50 \%$ flowering and panicle $\mathrm{m}^{-2}$ between hybrids and check cultivars grown during the 2010 dry season at N'Debougou in Mali (Table 3a). The average plant height for the hybrids was $108 \mathrm{~cm}$ and $111 \mathrm{~cm}$ for the check cultivars. The tallest hybrid, among those out-yielding the best check, was 49youR24 $(122.5 \mathrm{~cm})$. The hybrid 49youR24 had the highest number of spikelets per panicle (242), which was about $49 \%$ above the best check WITA 9. The average 1000 -grain weight of this hybrid (27.5 g) was $23 \%$ higher than the average of the checks (23.5 g). Grain yield of the high-yielding promising hybrids ranged from 11.5 to $12.5 \mathrm{t} \mathrm{ha}^{-1}$, but there were not significantly different that the best check cultivar WITA $9\left(10.2 \mathrm{t} \mathrm{ha}^{-1}\right)$.

There was an early 50\% flowering for both hybrids (88 days) and checks (95 days) during the 2010 wet season at Niono, Mali (Table 2b). XYR24 was the earliest (82 days) among the most promising hybrids due to their high grain yield, though most of these hybrids (and high yielding checks) were among the tallest in this trial. The best hybrids and check cultivar had a high number of spikelets per panicle (152-254). On average the hybrids had less panicles per $\mathrm{m}^{2}(292)$ than the check 
cultivars (325), but the hybrid GXY803067 had the most panicles (347). The hybrids' grains weighed higher than the check cultivars; and the hybrid CYX2 had the largest grains. Only one hybrid showed a significantly higher grain yield $\left(14.7 \mathrm{t} \mathrm{ha}^{-1}\right)$ than the best cultivar check NericaL-19 $\left(10.6 \mathrm{t} \mathrm{ha}^{-1}\right)$.

Table 3. Grain yield and other agronomic traits of promising rice hybrids and best cultivar check (C) in 2010 at (a) N'Debougou, Mali dry season and (b) Niono, Mali wet season. The $p$-value indicates that hybrids' yield was significantly higher that WITA 9 and NERICA-L19. Standard errors (S.E.) given for each trait.

\begin{tabular}{|c|c|c|c|c|c|c|c|c|}
\hline Cultivar & $\begin{array}{c}\text { Days to } \\
50 \% \\
\text { Flowering }\end{array}$ & $\begin{array}{l}\text { Plant } \\
\text { Height } \\
(\mathrm{cm})\end{array}$ & $\begin{array}{c}\text { Panicle } \\
\left(\mathrm{m}^{2}\right)\end{array}$ & $\begin{array}{l}\text { Spikelets } \\
\text { Panicle }^{-1}\end{array}$ & $\begin{array}{c}1000 \\
\text { Grain } \\
\text { Weight (g) }\end{array}$ & $\begin{array}{l}\text { Grain } \\
\text { Yield } \\
\left(\mathrm{t} \mathrm{ha}^{-1}\right)\end{array}$ & $\begin{array}{c}\text { Yield } \\
\text { Advantage } \\
(\%)\end{array}$ & $p$-Value \\
\hline \multicolumn{9}{|c|}{ (a) N'Debougou Dry Season } \\
\hline HanF1-35 & 88 & 111 & 168 & 158 & 19.8 & 12.5 & 22.31 & 0.0938 \\
\hline HS33 & 94 & 108 & 228 & 126 & 27.2 & 12.0 & 17.42 & 0.1508 \\
\hline 49 youR24 & 96 & 122 & 288 & 242 & 27.5 & 11.5 & 12.52 & 0.2282 \\
\hline HanF1-22 & 95 & 117 & 175 & 187 & 24.5 & 11.5 & 12.52 & 0.2282 \\
\hline HanF1-30 & 98 & 105 & 214 & 212 & 28.5 & 11.5 & 12.52 & 0.2282 \\
\hline WITA 9 (C) & 96 & 109 & 245 & 162 & 22.4 & 10.2 & 0.00 & \\
\hline Hybrid mean & 96 & 108 & 238 & 164 & 25.5 & 6.3 & 8.58 & \\
\hline Check mean & 97 & 111 & 237 & 142 & 23.5 & 5.8 & & \\
\hline Hybrid S.E. & 4 & 7 & 27 & 27 & 2.1 & 2.8 & & \\
\hline Check S.E. & 2 & 3 & 11 & 11 & 0.8 & 2.4 & & \\
\hline \multicolumn{9}{|c|}{ (b) Niono Wet Season } \\
\hline QS2 & 92 & 117 & 281 & 246 & 22.3 & 14.7 & 38.57 & 0.046 \\
\hline GSR-H-0007 & 89 & 133 & 291 & 152 & 26.4 & 12.0 & 12.89 & 0.291 \\
\hline CXY2 & 90 & 112 & 331 & 218 & 31.4 & 12.0 & 12.89 & 0.291 \\
\hline QS3 & 90 & 124 & 300 & 175 & 26.8 & 11.7 & 9.78 & 0.339 \\
\hline ZhongyouR24 & 85 & 125 & 271 & 254 & 27.9 & 11.3 & 6.59 & 0.389 \\
\hline GXY803067 & 89 & 125 & 347 & 183 & 29.9 & 11.3 & 6.59 & 0.389 \\
\hline NERICA-L19 (C) & 92 & 143 & 255 & 209 & 25.2 & 10.6 & 0.00 & \\
\hline Hybrid mean & 88 & 122 & 292 & 215 & 28.0 & 8.4 & -4.99 & \\
\hline Check mean & 95 & 119 & 325 & 182 & 25.3 & 8.8 & & \\
\hline Hybrid S.E. & 2 & 7 & 45 & 20 & 2.0 & 2.4 & & \\
\hline Check S.E. & 1 & 3 & 20 & 9 & 0.9 & 1.1 & & \\
\hline
\end{tabular}

The early sowing date affected days to $50 \%$ flowering, and most of the hybrids and check cultivars have their blooming after 100 days in the 2009 dry season at Badeggi (Table 4a). The average number of days to $50 \%$ flowering was 104 for the hybrids and 109 days for the check cultivars. Most of the promising hybrids were dwarf to semi-dwarf in plant height; i.e., not exceeding $100 \mathrm{~cm}$. The most promising hybrids had more panicles per area than the best check WITA 4. Grain yield was on average very low for hybrids and checks ( 2.55 and $2.51 \mathrm{t} \mathrm{ha}^{-1}$, respectively). The grain yield of the most promising hybrids ranged between 4.9 and $5.6 \mathrm{tha}^{-1}$, which was at least $50 \%$ above the grain yield of the best check cultivar WITA 4. Most of the hybrids had early flowering (about two weeks of advantage than the average of the check cultivars) during the 2010 wet season at Wushishi. TY8022 was the earliest flowering (77 days) hybrid (Table 4b). Most hybrids and checks exhibited a tall plant height (112 and $119 \mathrm{~cm}$ on average, respectively). There were no significant differences for grain yield between most promising hybrids (ranging from 8.5 to $11.5 \mathrm{t} \mathrm{ha}^{-1}$ ) and best check WITA $1\left(8.5 \mathrm{t} \mathrm{ha}^{-1}\right)$.

\subsection{Grain Quality}

All hybrids and check cultivar had medium to long grain types (Table 5). Their grain shape was either medium or slender. The most promising hybrids exhibited milling recovery that was above the check Sahel 108. The hybrid ERHAO had high total milling recovery $(70 \%)$, slender grain shape and low GT. The hybrids WZY2, CNY 549, and IL YOU Z2 showed the highest total milling recovery (above 70\%). Only two promising hybrids had low GT while the others and Sahel 108 exhibited a medium GT. 
Table 4. Grain yield and other agronomic traits of promising rice hybrids and best cultivar check (C) at (a) Badeggi 2009 dry season and (b) Wushishi 2010 wet season. The $p$-value indicates that the hybrids' yield was higher that WITA1 and WITA4. Standard errors (S.E.) given for each trait.

\begin{tabular}{|c|c|c|c|c|c|c|}
\hline Cultivar & $\begin{array}{c}\text { Days to } 50 \% \\
\text { Flowering }\end{array}$ & $\begin{array}{c}\text { Plant } \\
\text { Height }(\mathrm{cm})\end{array}$ & $\begin{array}{c}\text { Panicle } \\
\left(m^{-2}\right)\end{array}$ & $\begin{array}{l}\text { Grain Yield } \\
\left(\mathrm{t} \mathrm{ha} \mathrm{h}^{-1}\right)\end{array}$ & $\begin{array}{c}\text { Yield } \\
\text { Advantage (\%) }\end{array}$ & $p$-Value \\
\hline \multicolumn{7}{|c|}{ (a) Badeggi 2009 Dry Season } \\
\hline HanF1-26 & 104 & 87 & 294 & 5.6 & 58.51 & 0.0267 \\
\hline XYR24 & 101 & 93 & 395 & 5.4 & 74.92 & 0.0078 \\
\hline 3LYR24 & 112 & 98 & 325 & 5.1 & 66.25 & 0.0151 \\
\hline WZY2 & 109 & 73 & 293 & 4.9 & 51.08 & 0.0447 \\
\hline WITA 4 (C) & 111 & 83 & 279 & 3.2 & 0.00 & \\
\hline $\begin{array}{c}\text { Hybrid } \\
\text { mean }\end{array}$ & 104 & 93 & 248 & 2.6 & 1.59 & \\
\hline Check mean & 109 & 88 & 301 & 2.5 & & \\
\hline Hybrid S.E. & 6 & 16 & 72 & 0.9 & & \\
\hline Check S.E. & 2 & 6 & 29 & 0.3 & & \\
\hline \multicolumn{7}{|c|}{ (b) Wushi } \\
\hline GSR-H-0141 & 85 & 104 & 17 & 11.5 & 35.50 & 0.144 \\
\hline WZY2 & 84 & 114 & 11 & 9.2 & 9.08 & 0.392 \\
\hline GXY3169 & 92 & 126 & 12 & 9.2 & 8.84 & 0.395 \\
\hline IIyou623 & 96 & 112 & 13 & 8.9 & 4.83 & 0.442 \\
\hline TY8022 & 77 & 114 & 12 & 8.7 & 2.12 & 0.475 \\
\hline Huayou7109 & 79 & 118 & 12 & 8.5 & 0.59 & 0.493 \\
\hline WITA 1 (C) & 103 & 146 & 15 & 8.5 & 0.00 & \\
\hline $\begin{array}{c}\text { Hybrid } \\
\text { mean }\end{array}$ & 84 & 117 & 11 & 6.8 & 17.12 & \\
\hline Check mean & 99 & 119 & 15 & 5.8 & & \\
\hline Hybrid S.E. & 16 & 7 & 4 & 2.7 & & \\
\hline Check S.E. & 7 & 3 & 2 & 1.2 & & \\
\hline
\end{tabular}

Table 5. Grain traits and milling properties of promising rice hybrids and cultivar check (C) Sahel 108 after harvest in Ndjaye, Senegal during 2009 wet season.

\begin{tabular}{ccccccc}
\hline Hybrid & $\begin{array}{c}\text { Brown Rice } \\
\text { Length } \mathbf{( m m )}\end{array}$ & $\begin{array}{c}\text { Grain } \\
\text { Length }\end{array}$ & $\begin{array}{c}\text { Grain } \\
\text { Shape }\end{array}$ & $\begin{array}{c}\text { Total } \\
\text { Milling (\%) }\end{array}$ & $\begin{array}{c}\text { Alkali-Spreading } \\
\text { Value }\end{array}$ & $\begin{array}{c}\text { Gelanization } \\
\text { Temperature (GT) }\end{array}$ \\
\hline QY 1 & 6.3 & Medium & Medium & 68 & 5.67 & Low \\
HAN F1-47 & 6.4 & Medium & Medium & 69 & 4.00 & Intermediate \\
HS 706 & 6.2 & Medium & Slender & 70 & 4.58 & Intermediate \\
HAN F1-39 & 6.3 & Medium & Medium & 66 & 3.67 & Intermediate \\
HAN F1-36 & 6.8 & Long & Slender & 67 & 3.50 & Intermediate \\
PLY 1108 & 6.1 & Medium & Medium & 70 & 5.67 & Low \\
QY 3 & 6.4 & Medium & Medium & 66 & 4.00 & Intermediate \\
ERHAO & 6.1 & Medium & Slender & 70 & 6.67 & Low \\
HAN F1-26 & 6.7 & Long & Slender & 69 & 3.50 & Intermediate \\
HAN F1-31 & 6.6 & Long & Medium & 69 & 3.33 & Intermediate \\
YX 9 & 6.9 & Long & Medium & 68 & 5.33 & Intermediate \\
WZY 2 & 6.0 & Medium & Medium & 72 & 4.67 & Intermediate \\
HAN F1-10 & 6.4 & Medium & Medium & 70 & 3.42 & Intermediate \\
GXY-207 & 6.9 & Long & Slender & 69 & 3.50 & Intermediate \\
CNY 549 & 6.1 & Medium & Medium & 72 & 3.50 & Intermediate \\
HAN F1-9 & 6.2 & Medium & Medium & 70 & 4.42 & Intermediate \\
IL YOU Z2 & 5.8 & Medium & Medium & 71 & 4.25 & Intermediate \\
Sahel 108 (C) & 6.1 & Medium & Slender & 65 & 3.33 & Intermediate \\
\hline
\end{tabular}

\subsection{Host Plant Resistance}

Most of the 122 hybrids evaluated at a paddy screen house in Ibadan 2009 were highly susceptible to AfRGM. Only four hybrids (Han F1-21, YG 206, HS 33, and YG 17) were moderately susceptible to this insect pest (Table 6a), while the hybrid FFY66 showed partial resistance (5.9\% tiller infestation) to AfRGM under natural infestation during the 2010 wet season at Edozhigi (Table 6b). Among hybrids, 
FFY66 had the lowest mean plant damage and could be described as possessing an acceptable level of resistance to the pest. The hybrid FFY66 needs to be further evaluated at Edozhigi to confirm its stability and acceptability as possessing desirable or appreciable level of host plant resistance to AfRGM. The population structure of AfRGM in different rice farming systems in West Africa revealed that the biotype at Edozhigi is a virulent type-hence, the high susceptibility of the hybrids to this pest. The percent tiller infestation reduced at 63 days because of other parasites in the fields.

Table 6. Host plant resistance of most promising rice hybrids plus resistant and susceptible check cultivars to African rice gall midge after artificial infestation in screen house at (a) Ibadan 2009 wet season and (b) Edozhigi 2010 wet season.

\begin{tabular}{|c|c|c|c|c|}
\hline Cultivar & $\begin{array}{l}\text { Tiller Infestation } \\
\text { (\%) at } 45 \text { DAT }^{z}\end{array}$ & $\begin{array}{l}\text { Tiller Infestation } \\
\text { (\%) at } 70 \text { DAT }\end{array}$ & $\begin{array}{c}\text { Mean Tiller } \\
\text { Infestation (\%) }\end{array}$ & $\begin{array}{c}\text { Host plant } \\
\text { Resistance Rating }\end{array}$ \\
\hline \multicolumn{5}{|c|}{ (a) Ibadan 2009 Wet Season } \\
\hline Han F1-21 & 7.5 & 16.1 & 11.8 & MS \\
\hline YG 206 & 20.5 & 17.1 & 18.8 & MS \\
\hline HS 33 & 12.3 & 26.4 & 19.4 & MS \\
\hline YG 17 & 21.0 & 18.1 & 19.6 & MS \\
\hline ITA 306 (S) & 32.1 & 54.0 & 43.1 & HS \\
\hline TOS14519 (R) & 0.3 & 0.3 & 0.3 & $\mathrm{R}$ \\
\hline \multicolumn{5}{|c|}{ (b) Edozhigi 2010 Wet Season } \\
\hline FFY66 & 5.9 & 4.4 & 5.3 & MR \\
\hline Hanyou3 & 10.0 & 4.5 & 7.2 & MS \\
\hline HuF1-8 & 11.2 & 3.4 & 7.3 & MS \\
\hline FFY366 & 7.7 & 8.5 & 8.1 & MS \\
\hline EYH2 & 11.9 & 5.5 & 8.7 & MS \\
\hline QS2 & 12.7 & 4.9 & 8.8 & MS \\
\hline Huhan7A/07ZR15 & 11.0 & 7.2 & 9.1 & MS \\
\hline HLYR24 & 10.9 & 8.9 & 9.9 & MS \\
\hline CXY6 & 14.8 & 5.8 & 10.3 & MS \\
\hline CXY2 & 15.4 & 5.4 & 10.4 & MS \\
\hline HuF1-18 & 16.5 & 4.4 & 10.4 & MS \\
\hline Huhan9A/07ZR15 & 16.6 & 4.4 & 10.5 & MS \\
\hline ITA 306 (S) & 20.7 & 14.9 & 17.8 & S \\
\hline TOS 14519 (R) & 1.0 & 0.9 & 1.0 & $\mathrm{R}$ \\
\hline
\end{tabular}

${ }^{\mathrm{z}}$ Days after transplanting, ${ }^{\mathrm{y}} \mathrm{R}$ : resistant, MS: moderately susceptible, HS: highly susceptible (after [20]).

Table 7. Percentage of rice hybrids showing host plant resistance to Rice Yellow Mottle Virus strains $\mathrm{Ng}-01$ and Ng-40.

\begin{tabular}{|c|c|c|c|c|}
\hline $\begin{array}{l}\text { Days after } \\
\text { Inoculation }\end{array}$ & Isolate & $\begin{array}{l}\text { Number of Lines } \\
\text { Per Cluster }\end{array}$ & $\begin{array}{l}\text { Host Plant } \\
\text { Resistance }^{\mathrm{z}}\end{array}$ & $\begin{array}{c}\text { Hybrid Resistance } \\
\text { (\%) }\end{array}$ \\
\hline \multirow{6}{*}{21} & \multirow{3}{*}{$\mathrm{Ng}-01$} & 36 & $\mathrm{R}$ & 35.3 \\
\hline & & 0 & MS & 0.0 \\
\hline & & 66 & $S$ & 64.7 \\
\hline & \multirow{3}{*}{$\mathrm{Ng}-40$} & 26 & $\mathrm{R}$ & 25.5 \\
\hline & & 31 & MS & 30.4 \\
\hline & & 45 & $\mathrm{~S}$ & 44.1 \\
\hline \multirow{6}{*}{42} & \multirow{3}{*}{$\mathrm{Ng}-01$} & 5 & $\mathrm{R}$ & 4.9 \\
\hline & & 25 & MS & 24.5 \\
\hline & & 72 & $S$ & 70.6 \\
\hline & \multirow{3}{*}{$\mathrm{Ng}-40$} & 0 & $\mathrm{R}$ & 0.0 \\
\hline & & 28 & MS & 27.5 \\
\hline & & 74 & $S$ & 72.5 \\
\hline
\end{tabular}

${ }^{\mathrm{z}}$ R: resistant, MS: moderately susceptible. 
The hybrids were in four clusters according to their host plant resistance to blast when comparing them to known resistance and susceptible standard cultivars and NIL. We noted that two NIL bearing the same resistant gene (IRBLzt-IR56/CO and C104PKT) were in two contrasting clusters. This result could be due to either a non-detected additional major gene or minor sensitive resistant genes [24,25]. The highly resistant cluster included 49 hybrids, while there were 28 hybrids showing partial resistance, 23 hybrids were susceptible, and the remaining 22 hybrids were rated as highly susceptible.

There were $23 \%$ and $32 \%$ of the hybrids showing host plant resistance to isolates Ng- 40 and Ng-01 after two weeks from inoculation (Table 6). With the epidemic progression, none of the hybrids showed host plant resistance to $\mathrm{Ng}-40$ as the resistant check, but $18 \%$ hybrids were moderately susceptible. There were five hybrids rated as resistant, as the resistant check to isolate Ng-01 (Table 7).

\section{Discussion}

Hybrid rice seed technology was developed in China more than 35 years ago. Many of the released rice hybrids have shown between $15 \%$ and $20 \%$ grain yield advantage over inbred cultivars in Asia, South America, and Egypt [26,27]. These results encouraged some to test hybrid rice in sub-Saharan Africa. Our previous research indicated that the grain yield of IRRI-bred hybrids was similar to that of check cultivars in Senegal [28]. This research shows, however, that there was a high yield potential of hybrid rice bred in China after testing them in Mali, Nigeria, and Senegal. The grain yield of the most promising hybrids was higher than that of the best local inbred check cultivar. The hybrids exhibited a wide range grain yield, which was affected by the testing location and growing season.

The genotype $\times$ environment interactions $(G \times E)$ were highly significant for both sets of the hybrids and their respective cultivar checks across the three countries; i.e., their performances were different across sites from country to country. There was not the same hybrid or check cultivar showing superiority over others across the sites used in these three countries. This result may be due the soil characteristics, fertilizer applications, and weather conditions in the sites used for testing. The results of this study exhibited the high potential of these hybrids under the optimum conditions (Mali and Senegal), while the yield affected by RYMV and AfRGM stresses (in Nigeria). This finding suggests developing different hybrids for each region. In West Africa, high rice grain yields are often associated with high solar radiation, high maximum temperature, intermediate air humidity, multiple split nitrogen $(\mathrm{N})$ fertilizer applications, high frequency of weeding operations, the use of certified seeds, and well-leveled fields in the irrigated lowland system [29]. Local cultivars with host plant resistance to pathogens and pest may be used to develop new hybrids with high adaptability to stress-prone African sites.

The most promising hybrids across the testing locations had $20 \%$ more grain yield than the best check cultivars. This additional grain yield advantage may encourage some African farmers to grow hybrid rice cultivars. Testing sites in Mali and Senegal have irrigated areas with higher solar radiation than the Nigerian testing site [30], which could be optimum environments for rice hybrids to show their heterosis for grain yield. The most promising hybrids also showed a good plant type and other interesting attributes. For example, most of them had medium or slender grain shape and higher milling recovery than the preferred check cultivar. Likewise, two hybrids had low GT, thereby needing less energy inputs for their cooking.

A major shortcoming of most of the hybrids bred in China is their susceptibility to both AfRGM and RYMV. Host plant resistance to both of them needs to be bred or incorporated into the parental lines of the hybrid rice germplasm before their release to West African farmers. In order words, indigenous parental lines such as traditional African (O. glaberrima) and Asian (O. sativa) rice-derived cultivars grown already in West Africa are proven useful sources of resistance to AfRGM and RYMV. They should be used in developing hybrids for farmers in West Africa. The levels of resistance shown in O. glaberrima gene pool are better than those of found in O. sativa. TOG7106 and TOS14519 were rated highly stable and highly resistant to AfRGM [31]. Crossing should be made with donors that possess multiple tolerance to biophysical stresses, and off-sites should be used to select appropriate lines from 
segregating generations [32]. Recently the major QTL of AfRGM were located and validated [11], being the QTL with major effect (qAfRGM4) on chromosome 4. They could be easily incorporated into the parental lines of the promising hybrids through marker-aided backcrossing [33]. Knowledge on the distribution of virulent RYMV populations across different target sites will also help to deploy safely rice hybrids in sub-Saharan Africa. It was interesting to note that in excess of $60 \%$ of the hybrids were either partially resistant (with slight symptoms) or highly resistant (without any symptom) to blast. Moreover, multi-environment testing will be still necessary to assess whether their host plant resistance will remain across space and time. Microsatellite-aided screening for fertility restoration genes $R f$ may further facilitate hybrid development with high adaptability in West Africa [34]. Preliminary results are promising: some adapted breeding lines and cultivars had high grain yield per plant with cytoplasmic male sterility lines and may be used as fertility restorers.

Acknowledgments: We are grateful for the assistance given by Ngoni Jiri, the AGRITEX officer for Chiota, and for the assistance by the Chiota community during data collection. This work was supported by the International Foundation of Science (IFS) (grant C/4569-1); DAAD Fellowship (grant number A/10/03022) and the Climate Food and Farming (CLIFF) network under the CGIAR Research Program on Climate Change, Agriculture and Food Security (CCAFS).

Author Contributions: Raafat El-Namaky and Baboucarr Manneh conceived and designed the experiments; Raafat El-Namaky, Mamadou M. Bare Coulibaly, Maji Alhassan, Karim Traore, Francis Nwilene, Ibnou Dieng, and Baboucarr Manneh performed the experiments; Raafat El-Namaky, Karim Traore, Francis Nwilene, Ibnou Dieng, Baboucarr Manneh; and Rodomiro Ortiz analyzed the data and wrote the paper.

Conflicts of Interest: The authors declare no conflict of interest. The founding sponsors had no role in the design of the study; in the collection, analyses, or interpretation of data; in the writing of the manuscript, or in the decision to publish the results.

\section{References}

1. International Rice Research Institute (IRRI); Africa Rice; CIAT. Global Rice Science Partnership (GRiSP); International Rice Research Institute: Los Baños, Philippines, 2010.

2. Seck, P.A.; Diagne, A.; Mohanty, S.; Wopereis, M.C.S. Crops that feed the world 7: Rice. Food Sec. 2012, 4, 7-24. [CrossRef]

3. Nguyen, N.V.; Ferrero, A. Meeting the challenges of global rice production. Paddy Water Environ. 2006, 4, 1-9. [CrossRef]

4. Balasubramanian, V.; Sie, M.; Hijmans, R.J.; Otsuka, K. Increasing rice production in sub-Saharan Africa: Challenges and opportunities. Adv. Agron. 2007, 94, 55-132. [CrossRef]

5. Bentolila, S.; Alfonso, A.A.; Hanson, M.R. A pentatricopeptide repeat-containing gene restores fertility to cytoplasmic male sterile plants. Proc. Natl. Acad. Sci. USA 2002, 99, 10887-10892. [CrossRef] [PubMed]

6. Bastawisi, A.O.; El-Mowafi, H.F.; Abo Yousef, M.I.; Draz, A.E.; Aidy, I.R.; Maximos, M.A.; Badawi, A.T. Hybrid Rice Research and Development in Egypt. In Hybrid Rice for Food Security, Poverty Alleviation and Environmental Protection, Proceedings of the 4th International Symposium on Hybrid Rice, Hanoi, Vietnam, 14-17 May 2002; Virmani, S.S., Mao, C.X., Hardy, B., Eds.; International Rice Research Institute: Los Baños, Philippines, 2003; pp. 257-263.

7. Yuan, L.P. Hybrid Rice Breeding in China. In Advances in Hybrid Rice Technology, Proceedings of the 3rd International Symposium on Hybrid Rice, Hyderabad, India, 12-14 November 1996; Virmani, S.S., Siddiq, E.A., Muralidharan, K., Eds.; International Rice Research Institute: Metro Manila, Philippines, 1988; pp. $592-607$.

8. He, G.T.; Zhu, X.; Gu, H.Z.; Flinn, J.C. The use of hybrid rice technology: An economic evaluation. In Hybrid Rice; International Rice Research Institute: Los Baños, Philippines, 1988; pp. 229-241.

9. Nwilene, F.E.; Traore, A.K.; Asidi, A.N.; Sere, Y.; Onasany, A.; Abo, M.E. New records of insect vectors of Rice Yellow Mottle Virus (RYMV) in Côte d'Ivoire, West Africa. J. Entomol. 2009, 6, 198-206. [CrossRef]

10. Nacro, S.; Heinrichs, E.A.; Dakouo, D. Estimation of rice yield losses due to the African rice gall midge, Orseolia oryzivora Harris and Gagne. Int. J. Pest Manag. 1996, 42, 331-334. [CrossRef]

11. Yao, N.; Lee, C.R.; Semagn, K.; Sow, M.; Nwilene, F.; Kolade, O.; Bocco, R.; Oyetunji, O.; Mitchell-Olds, T.; Ndjiondjop, M.N. QTL mapping in three rice populations uncovers major genomic regions associated with African rice gall midge resistance. PLoS ONE 2016, 11, e0160749. [CrossRef] [PubMed] 
12. Kouassi, N.K.; Guessan, P.N.; Albar, L.; Fauquet, C.M.; Brugidou, C. Distribution and characterization of Rice Yellow Mottle Virus: A threat to African farmers. Plant Dis. 2005, 89, 124-132. [CrossRef]

13. Joseph, A.; Olufolaji, D.B.; Nwilene, F.E.; Onasanya, A.; Omole, M.M. Effect of leaf age on Rice Yellow Mottle Virus severity and chlorophyll content with mechanical inoculation and vector transmission method. Trends Appl. Sci. Res. 2011, 6, 1345-1351. [CrossRef]

14. Onwughalu, J.T.; Abo, M.E.; Okoro, J.K.; Onasanya, A.; Sere, A. Rice Yellow Mottle Virus infection and reproductive losses on rice (Oryza sativa L.). Trends Appl. Sci. Res. 2011, 6, 182-189. [CrossRef]

15. Sere, Y.; Onasanya, A.; Nwilene, F.E.; Abo, M.E.; Akator, S.K. Potential of insect vector screening method for development of durable resistant cultivars to Rice Yellow Mottle Virus disease. Int. J. Virol. 2008, 4, 4-47. [CrossRef]

16. Couch, B.C.; Kohn, L.M. A multilocus gene genealogy concordant with host preference indicates segregation of a new species, Magnaporthe oryzae, from M. grisea. Mycologia 2002, 94, 683-693. [CrossRef] [PubMed]

17. Bonman, J.M.; Mackill, D.J. Durable resistance to rice blast disease. Oryza 1988, 25, 103-110.

18. Vera Cruz, C.M.; Kobayashi, N.; Fukuta, Y. Rice blast situation, research in progress, needs and priorities in 13 countries: Summary of results from a blast survey. JIRCAS Work. Rep. 2007, 53, 97-103.

19. Federer, W.T. Augmented (or hoonuiaku) designs. Hawaii. Plant. Rec. 1956, 55, 191-208.

20. IRRI. Standard Evaluation System for Rice, 4th ed.; International Rice Research Institute: Los Baños, Philippines, 1996. Available online: http://www.knowledgebank.irri.org/images/docs/rice-standard-evaluationsystem.pdf (accessed on 9 July 2017).

21. Sere, Y.; Sy, A.A.; Sie, M.; Akator, S.K.; Onasanya, A.; Kabore, B.; Conde, C.K.; Traore, M.; Kiepe, P. Importance of Varietal Improvement for Blast Disease Control in Africa; JIRCAS Working Report 70; Japan International Research Centre for Agricultural Sciences: Tsukuba, Japan, 2011.

22. Finninsa, C. Relationship between common bacterial blight severity and bean yield loss in pure stand and bean-maize intercropping system. Int. J. Pest Manag. 2003, 49, 177-185. [CrossRef]

23. Littel, R.C.; George, A.M.; Walter, W.S.; Russell, D. SAS System for Mixed Models; SAS Institute Inc.: Cary, NC, USA, 1996.

24. Mekwatanakarn, P.; Kositratana, W.; Levy, M.; Zeigler, R.S. Pathotype and avirulence gene diversity of Pyricularia grisea in Thailand as determined by rice lines near-isogenic for major resistance genes. Plant Dis. 2000, 84, 60-70. [CrossRef]

25. Sere, Y.; Onasanya, A.; Afolabi, A.; Mignouna, H.D.; Akator, K. Genetic diversity of the blast fungus, Magnaporthe grisea (Hebert) Barr, in Burkina Faso. Afr. J. Biotech. 2007, 6, 2568-2577.

26. Cheng, S.H.; Zhuang, J.Y.; Fan, Y.Y.; Du, J.H.; Cao, L.Y. Progress in research and development on hybrid rice: A super-domesticate in China. Ann. Bot. 2007, 100, 959-966. [CrossRef] [PubMed]

27. El-Mowafi, H.F.; Bastawisi, A.O.; Abdekhalek, A.F.; Attia, K.A.; El-Namaky, R.A. Hybrid rice technology in Egypt. In Accelerating Hybrid Rice Development, Proceedings of the 5th International Symposium on Hybrid Rice, Changsha, China, 12-14 September 2008; Xie, F., Hardy, B., Eds.; International Rice Research Institute: Los Baños, Philippines, 2008; pp. 592-607.

28. Kanfany, G.; El-Namaky, R.; Ndiaye, K.; Traore, K.; Ortiz, R. Assessment of rice inbred lines and hybrids under low fertilizer levels in Senegal. Sustainability 2014, 6, 1153-1162. [CrossRef]

29. Abibou, N.; Becker, M.; Ewert, F.; Dieng, I.; Gaiser, T.; Tanaka, A.; Senthilkumar, K.; Rodenburg, J.; Johnson, J.M.; Akakpo, C.; et al. Variability and determinants of yields in rice production systems of West Africa. Field Crops Res. 2017, 207, 1-12. [CrossRef]

30. Dingkuhn, M.; Saw, A. Potential yield of irrigated rice in the Sahel. In Irrigated Rice in the Sahel: Prospects for Sustainable Development; Miezan, K.M., Wopereis, M.C.S., Dinkuhn, M., Deckers, J., Randolph, T.F., Eds.; West Africa Rice Development Association: Bouaké, Côte d'Ivoire, 1997; pp. 361-379.

31. Nwilene, F.E.; Williams, C.T.; Ukwungwu, M.N.; Dakouo, D.; Nacro, S.; Hamadoun, A.; Kamara, S.I.; Okhidievbie, O.; Abamu, F.J.; Adam, A. Reactions of differential rice genotypes to African rice gall midge in West Africa. Int. J. Pest Manag. 2002, 48, 195-201. [CrossRef]

32. Singh, B.N.; Williams, C.T.; Ukwungwu, M.N.; Maji, A.T. Breeding for resistance to African rice gall midge, Orseolia oryzivora Harris and Gagné. In New Approaches to Gall Midge Resistance in Rice; Bennett, J., Bentur, J.S., Pasalu, I.C., Krishnaiah., K., Eds.; International Rice Research Institute: Metro Manila, Philippines, 2004; pp. 121-130. 
33. Himabindu, K.; Sundaram, R.M.; Neeraja, C.N.; Mishra, B.; Bentur, J.S. Flanking SSR markers for allelism test for the Asian rice gall midge (Orseolia oryzae) resistance genes. Euphytica 2007, 157, 267-279. [CrossRef]

34. El-Namaky, R.; Seedek, S.; Moukoumbi, Y.D.; Ortiz, R.; Manneh, B. Microsatellite-aided screening for fertility restorer genes $(R f)$ facilitates hybrid improvement. Rice Sci. 2016, 23, 160-164. [CrossRef] 